\title{
Entrevista com Ariel Ortega, cineasta Mbyá-Guarani
}

Luisa Tombini Wittmann ${ }^{1}$

Marcelo Téo ${ }^{2}$

Quem é você?

Eu sou Ariel, trabalho com cinema. Ariel Kuaray Poty, em guarani. Raio do sol. Sou descendente da morada do deus do sol.

Aílton Krenak costuma dizer que o cinema indígena é uma revolta do olhar, pois rompe com a imagem pasteurizada criada pelo cinema hollywoodiano. Como você enxerga o cinema indígena? Quando falamos em cinema indígena, sua maneira de fazer imagens, de chegar com a câmera, não podemos dizer que é tudo igual. O nosso jeito guarani de fazer cinema talvez seja um pouco diferente dos Kuikuro fazerem cinema, é outra cosmologia, até outro ritmo de filmar. Talvez tenha outro tempo também. Por exemplo, eu, toda vez que pego a câmera, sempre tento que aquela câmera entre como um guarani e tenha também esse tempo guarani. Eu tenho que respeitar o tempo de um Karaí que eu esteja entrevistando porque ele tem todo o seu tempo, tem que ter inspiração para, depois, finalmente falar. E eu tenho que ter tempo de ficar gravando. Os planos tem que ser mais longos para ter essa sensação, para não mudar muito o ritmo e o tempo guarani.

No cinema guarani, especificamente, você considera que se trabalha com o imprevisível numa autoria coletiva?

Não dá para escrever o roteiro antes porque tudo pode mudar, tem a ver com o ritmo da aldeia, como estão as pessoas, as lideranças. No meio das filmagens tudo pode mudar, fazemos várias reuniões. A gente sempre tenta acompanhar o que está rolando naquele momento, naquela época. Na primavera, são conversas sobre as plantações, colheitas, preparações de terra. No inverno, observamos o que está acontecendo, quais são as atividades. Então não temos o roteiro pronto, para que os jovens que estão fazendo as oficinas [de audiovisual] possam ir descobrindo a procurar

\footnotetext{
${ }^{1}$ Doutora em História pela Universidade Estadual de Campinas (Unicamp). Atualmente é professora do curso de História e pós-graduação em História da Universidade do Estado de Santa. E-mail: luwittmann@ gmail.com

${ }^{2}$ Doutor em História Social pela Universidade de São Paulo (USP). Graduou-se em História pela Universidade do Estado de Santa Catarina, onde também cursou Licenciatura em Música.
} 
a história, a aprender a contar a história através do cinema. E para que a comunidade mesmo participe, porque os filmes são da comunidade. Toda a comunidade tem que estar sabendo o que a gente está fazendo. A gente projeta o material bruto durante a noite com a comunidade. A gente chama todo mundo, sempre.

\section{Qual a importância do audiovisual para dentro da comunidade indígena?}

É muito importante como registro, como memória. Todos os conhecimentos, tudo a gente aprende escutando e guarda na memória, desde criança. Mas muitas dessas coisas, assim como em qualquer outra cultura, também vão se perdendo. Por exemplo, hoje em dia, a maioria das comunidades já tem escola e as crianças não estão mais crescendo como antigamente, não ficam na beira da fogueira durante a tarde, vão perdendo um pouco essa coisa da oralidade, dos líderes falarem sobre a nossa cultura, o nosso jeito de ser guarani. Hoje em dia tecnologias estão chegando muito rápido dentro da aldeia, como celulares, redes sociais, computadores, televisão. O cinema é muito importante para termos materiais nossos, filmados dentro da aldeia pela gente mesmo. Tudo isso é mostrado dentro da aldeia, e também assistimos os trabalhos de outras aldeias para saber como a nossa aldeia é diferente, quais são as dificuldades, os problemas de território. Por exemplo, o filme Bicicletas de Nhanderú mostra muito os dois meninos cruzando a cerca da fazenda para fazer armadilha e buscar lenha, são algumas questões que outras aldeias talvez não saibam, e os próprios não indígenas principalmente. $\mathrm{E}$ isso vai gerando discussões dentro da aldeia, então é uma ferramenta política também para os jovens, isso dá muito apoio para as próprias lideranças. Não somente política, mas para algumas questões ou problemas internos que muitas vezes temos dentro da aldeia. Algumas vezes a gente não enxerga e, quando faz o filme, finalmente a gente acorda e vê o filme nos olhando, na tela. Eu aprendi muitas coisas da minha cultura conversando com os Karaí, e isso para mim foi muito importante. Traduzindo eu aprendi muitas palavras que eu não sabia em guarani, algumas palavras mais filosóficas, porque muitas vezes quando os mais velhos falam muitos jovens hoje em dia não entendem, e eu traduzindo o material comecei a entender muitas coisas. Por isso também eu acho importante ter esse registro das falas, ter o material bruto, não somente para fazer o filme. Eu aprendi muito mesmo. 
Qual a importância do audiovisual para fora da comunidade indígena? Você considera relevante o uso desse material para a implementação da Lei 11.645/08, que tornou obrigatório o ensino de história e cultura indígena nas escolas brasileiras?

O filme Duas aldeias, uma caminhada foi feito para mostrar para fora, porque eu via muito preconceito. Os guaranis sempre estiveram por ali, mas as pessoas não conheciam a história de São Miguel das Missões, nem que os indígenas tinham construídos as ruínas. Isso me incomodava muito, e eu queria encontrar uma forma de contar melhor essa história. Poderia funcionar também fazer uma animação sobre mitologia, e isso ser estudado nas escolas. Para os indígenas a mitologia é muito importante, porque toda a nossa história é baseada na mitologia. E também sobre o conhecimento da medicina, o que é importante, preservar a natureza. Nesse mundo de capitalismo, de consumismo que estamos vivendo, estão tentando destruir tudo. Acho que é importante contar essa parte, preservar esse conhecimento dos povos indígenas para cuidar mais da natureza, do planeta mesmo. Estamos todos no mesmo barco. Os povos indígenas têm uma contribuição enorme para construir uma sociedade melhor.

Muitos não-indígenas se dão o direito de afirmar que o indígena deixa de ser indígena quando utiliza tecnologias. Como você responderia a isso?

Por que só por ser indígena a gente tem que ser manter isolado, congelado no tempo? Quando nossos avós, nossos antepassados, estavam lá como um indígena ideal, que o ocidental considera ideal, semi-nus com cocar na cabeça, sem nada de tecnologia, eram chamados de selvagens ou primitivos, e agora que usamos roupas e usamos a câmera deixamos de ser indígena. Não dá para entender muito isso. (risos) Existem outras culturas que são milenares e que inventaram muitas tecnologias, por exemplo, a própria câmera dos japoneses. É uma cultura milenar que é muito importante, mesmo assim eles fazem câmeras super modernas e ainda tem práticas que são milenares, por exemplo, o jeito de comer no chão, mas mesmo tendo toda essa tecnologia não deixaram de ser japoneses, não deixaram de ser uma cultura milenar. Acho que quando se trata assim dos indígenas, que deixaram de ser indígenas por usar celular ou qualquer outra tecnologia é por preconceito mesmo ou porque não sabe da realidade. Hoje em dia, querendo ou não, por exemplo, a gente come comidas dos não indígenas, mas por que que a gente está desse jeito? Porque todas as nossas matas foram destruídas, a gente tá morando na periferia ou na beira da estrada, não tem mais como plantar. Hoje em dia já não podemos mais, para defender nossas terras, 
lutar com arco e flecha. Eu estou usando a câmera de outra forma, como luta. É uma ferramenta ocidental mas que eu estou usando para me defender e para contar outra história, minha, que é dentro da aldeia. E de qualquer forma toda a matéria prima que foi usada para fabricar câmeras ou novas tecnologias foi tirada da terra. Meu avô falava muito que todo o conhecimento que os não indígenas têm, por exemplo, para criar novas tecnologias de alguma forma foi dado por Tupã, senão nunca teriam criado. Então a gente não vai, eu não vou ser menos indígena ou não vou deixar de ser indígena porque eu estou usando a câmera. É muito de como você está usando e para que. Por isso eu sempre digo que quando pego a câmera dentro da aldeia ela se transforma como um ser da aldeia também.

Você vem desenvolvendo um jeito de fazer cinema muito singular. Ao caminhar com a câmera na mão conversando com as pessoas, permite ao espectador olhar o mundo a partir de uma perspectiva guarani. Você encontra a história que quer contar ao mesmo tempo que faz parte dela, algo que muitos documentaristas ocidentais tentaram fazer, mas talvez não com o mesmo nível de profundidade.

Eu só consigo mesmo sentir quando estou filmando. É muito o momento, eu guarani, nosso jeito de ser guarani. Quando eu pego a câmera não é instantaneamente que eu entro na imagem. Demora um pouquinho para vir essa inspiração. E não é somente o filme. Na hora que eu estou fazendo eu não fico vendo o documentário futuramente, eu estou vivendo muito $100 \%$ ali. Nem um momento vem na minha cabeça: isso vai virar um documentário, eu estou fazendo um documentário. Eu acho que a diferença dos cineastas ocidentais é que na filmagem eles já tem um filme na cabeça, e para o meu ser eu estou no momento. O Karaí é uma pessoa sábia, eu fico sentindo todas as coisas, tenho que ficar olhando nos olhos, o suspiro. É muito difícil de explicar.

Você poderia nos contar um pouco sobre o filme que está sendo realizando no momento?

É um longa metragem. Acho que é ficção-documentário que a gente chama. Era meio proibido contar dentro da aldeia sobre essa história. Eu estava muito curioso, desde criança, só que ninguém contava. O filme trata da história de um homem que vira uma onça. Foram anos indo conversar com meu avô, meus tios dentro da aldeia, que viram realmente esse cara virar onça. $\mathrm{O}$ filme fala dos excessos que fazem mal, porque ele quebrava todas as regras da caça, do que um homem pode fazer, o que não pode fazer. Mas não somente mostrar, como personagem, mas também de entender 
um pouco mais esse mundo de transformação. Por que uma pessoa chega a se transformar? Existe toda uma parte mais espiritual. Toca também a parte da transformarão do ser guarani, desde a gravidez, como a família, os pais da criança tem que tratar, educar, antes mesmo da criança nascer, para ir se transformando. Dependendo do comportamento dos pais, a gente pode trocar o espírito dele, dentro do ventre. Quando nos casamos, nossos pais, nossos avós já falam como tem que ser nosso comportamento, nosso ser, para que o nosso filho nasça uma criança saudável. Toca toda essa parte da educação, do que é vir a ser guarani.

Como você percebe a diferença, ou não, entre ficção e realidade no seu modo de fazer cinema?

Eu falo ficção porque o cinema ocidental colocou esse nome. Mas para nós, não existe ficção ou realidade. Não existe culturalmente essa separação. Essa história que a gente está fazendo que eu falo que é ficção, na verdade para mim, para a comunidade que está contando a história, não é ficção. É transformação, metamorfose. Para os ocidentais não é possível alguma pessoa se transformar num animal. Para nós é muito normal, a gente aprende desde criança sobre essas coisas. É uma memória que está dentro da nossa alma. Quando eu crescer como cineasta eu quero fazer um filme sobre a criação do universo, sobre o que eu escutei de como surgiram os deuses, que o meu avô contava, que os guarani contam, nós guaranis. Eu fico imaginando de que forma filmar a criação do universo. Nhanderu-Tupã, os deuses trovões surgindo, papatenondé. Antes não existia nada, nem a luz, nem o sol, nada. Eu queria mostrar esse surgimento, e depois o futuro sol, o futuro lua vindo aqui na terra, criando as frutas, as árvores, colocando os nomes das coisas. E daí finalmente o sol se transforma no que o sol é agora, que a gente vê hoje em dia. Ele volta, deixa tudo pronto, a terra. Depois também existe a mãe deles, nossa mãe celestial, a deusa. Quando chega na morada das onças primitivas, porque antigamente todos os animais eram como pessoas, como a gente. Só depois que eles se transformaram nos animais que a gente vê. Por exemplo, os grilos, eram karaí também, os sábios grilos. Os macacos, as onças, tudo, eram como pessoas. E tudo isso existir como personagem, como conta a mitologia. Seria um sonho realizar esse filme.

Entrevista realizada em Florianópolis, no dia 02 de outubro de 2018. A entrevista completa, filmada, disponível em: www.ayalaboratorio.com 